\title{
Understanding How Sea Ice Influences Arctic Deep-Water Food Webs across
}

\section{a Latitudinal Gradient}

by Laurissa Christie

\section{INTRODUCTION}

$\mathrm{G}$ LOBAL MARINE ECOSYSTEMS ARE FACING numerous stressors, including the opening of new shipping pathways, invasive species, and climate change. In the Arctic Ocean, the ongoing loss of sea ice is predicted to increase surface water temperatures to $10^{\circ} \mathrm{C}$ by the year 2300 (Carton et al., 2015). This increase is concerning because the Arctic Ocean plays an important role in regulating the temperature, biogeochemical cycles, and the dynamics of global food webs (Harada, 2016). In combination, these stressors on Arctic ecosystems have the potential to influence the diversity, structure, and energy dynamics of food webs (Kortsch et al., 2015), which vary both spatially (with latitude) and temporally (within time) (McMeans et al., 2015).

To understand food webs and their response to change, the ecological niche of an individual can be defined as a hypervolume of $n$ dimensions in relation to resource use (Colwell and Rangel, 2009). Using a multidimensional approach to niche, it is possible to identify the relationship between diet composition (trophic level and resource availability) and habitat use (foraging behaviour) (Newsome et al., 2007). Niche characterization consequently provides a tool for understanding the role of species within an ecosystem and the interspecies interactions that influence species' ecological traits and energy transfer, as well as how an ecosystem responds to stressors and food web structure (Newsome et al., 2007; Bison et al., 2015).

Deep-water food webs are defined as assemblages of organisms below $200 \mathrm{~m}$ from the surface (Rogers, 2015; Priede, 2017). Despite being collectively the largest ecosystem on earth (99\% by volume; Norse et al., 2012), these food webs are little understood; they are difficult and expensive to access and study, particularly in the Arctic. Stable isotopes $\left(\delta^{13} \mathrm{C}\right.$ and $\left.\delta^{15} \mathrm{~N}\right)$ provide a cost-effective tool for understanding averaged diet history (Post, 2002), trophic level (Turner et al., 2010; Zimmo et al., 2012), and habitat connectivity (Inger and Bearhop, 2008), as well as for making inferences about an organism's niche and understanding the proportional contribution of basal carbon sources to species' diets (e.g., through Bayesian mixing models; Jackson et al., 2011; Phillips et al., 2014). Previous global work on $\delta^{13} \mathrm{C}$ and $\delta^{15} \mathrm{~N}$ values in species found in Arctic (Iken et al., 2005; Bergmann et al., 2009), canyon (Demopoulos et al., 2017), and seamount habitats (Preciado et al., 2017) indicates that deep-water food webs comprise approximately four to five trophic levels, ranging from primary producer to predators, with most species occupying trophic positions 2 to 4 (Iken et al., 2005; Valls et al., 2014; Preciado et al., 2017). However, only limited niche research has been done to provide a baseline for monitoring future human and climate change impacts as temperate species move farther north. In order to understand species' niches in deep-water communities and how these change over a latitudinal gradient, more work is needed.

Highly branched isoprenoid (HBI) biomarkers can form an index known as the H-Print (Brown et al., 2014a), which provides an approach complementary to the stable isotope method for examining the contributions of carbon derived from pelagic and sympagic (sea ice) sources (Brown and Belt, 2017). This biomarker tool provides a relative measure of the importance and transfer rate of sea ice-derived carbon to Arctic deep-water food webs (Brown and Belt, 2017). While studies have examined proportional origins of carbon across entire shallow-water Arctic food webs (Brown, 2018; Brown et al., 2018), as well as in zooplankton (Brown and Belt, 2012; Brown et al., 2017a), particulate organic matter (Brown et al., 2016), fishes (Brown and Belt, 2017; Brown et al., 2015, 2017b), beluga whales (Brown et al., 2017b), ringed seals (Brown et al., 2014b), and polar bears (Brown et al., 2018), researchers have yet to investigate the importance of sea-ice carbon to deep-water food webs that vary by latitude in ice cover and concentration. Within the Arctic, organismal samples usually contain six to seven HBIs, and primary productivity is mainly pelagic or sympagic (derived from sea ice) (Brown et al., 2014a). Dominant HBIs in Arctic tissue samples are often Ice Proxy 25, better known as " $\mathrm{IP}_{25}$ " (Belt et al., 2007), and HBI-II (Brown and Belt, 2017), which originate from within sea-ice algae; whereas HBIIII is found in phytoplankton, indicating pelagic sources (Belt et al., 2017; Brown and Belt, 2017; Brown et al., 2018). Applying the H-Print technique to deep-water species will provide information critical to understanding the role of sea ice and impacts of climate change to Arctic deep-water food webs under climate change predictions. 
Specifically, the study will examine temporal variation (seasonal and inter-annual) and spatial variation (at three sites with varying sea-ice extent and timing) in niche dynamics of deep-water species that adopt different foraging strategies and feed at various trophic levels (from primary consumers to predators). In addition, it will quantify the energy pathways that support deep-water species by examining the proportional contributions of two principal basal carbon sources: sympagic and pelagic. The overall objective of the study is to examine the architecture of Arctic deep-water food webs by examining species' roles across the entire ecosystem, which will aid the development, conservation, and management of sustainable fisheries.

\section{RESEARCH METHODS}

\section{Data Collection}

To examine the structure of deep-water Arctic food webs, invertebrates and fishes were collected using an otter trawl (1200 Campelen Shrimp trawl) and longline surveys (size \#12 circle hooks baited with squid; 200 hooks spaced $2 \mathrm{~m}$ apart followed by $800 \mathrm{~m}$ of weighted line as a spacer and then another $200 \mathrm{~m}$ of size \#12 hooks spaced $2 \mathrm{~m}$ apart), as well as from Inuit subsistence hunts. We studied three sites along the east coast of Baffin Island that differ in the timing of sea-ice formation and breakup, collecting samples at Scott Inlet in 2013 and at Pond Inlet and Qikiqtarjuaq in 2017 and 2018 (Fig. 1). Fishes and invertebrate samples were sorted (Fig. 2), frozen immediately at $-20^{\circ} \mathrm{C}$ onboard the M.V. Nuliajuk, and transported to the University of Windsor.

Data on the morphometric characteristics of species sampled, such as total length, body mass, and condition (e.g., hepatosomatic index for fishes) was collected in addition to tissue samples (liver, muscle, fin clips) with various tissue turnover rates (slow versus fast; muscle versus liver) (Heady and Moore, 2013) (Fig. 3). Tissue turnover rates for slow-growing (Xia et al., 2013) deepwater species are not well known, but estimates can be derived from Vander Zanden et al. (2015), who systematically reviewed animal tissue isotopic turnover data to develop a model for predicting turnover rates, on the assumption that high and low metabolic tissues will follow similar trends in slow-growing species. The same study also reported that as body mass increases, so does isotopic half-life. By analyzing tissues (muscle and liver) with variable turnover rates for stable isotopes $\left(\delta^{13} \mathrm{C}\right.$ and $\left.\delta^{15} \mathrm{~N}\right)$, we can obtain snapshots of both recent diet (from the liver tissue) and average dietary interactions over a longer time period (from muscle tissue). This multi-tissue approach helps us understand seasonal and interannual variation in niche dynamics of deep-water species. The relationship between morphometric characteristics and chemical tracers (H-Print, $\delta^{13} \mathrm{C}$ and $\delta^{15} \mathrm{~N}$ stable isotopes) of tissues is also considered for niche (e.g., whether or not larger species have larger niches and the impact of fitness on niche).

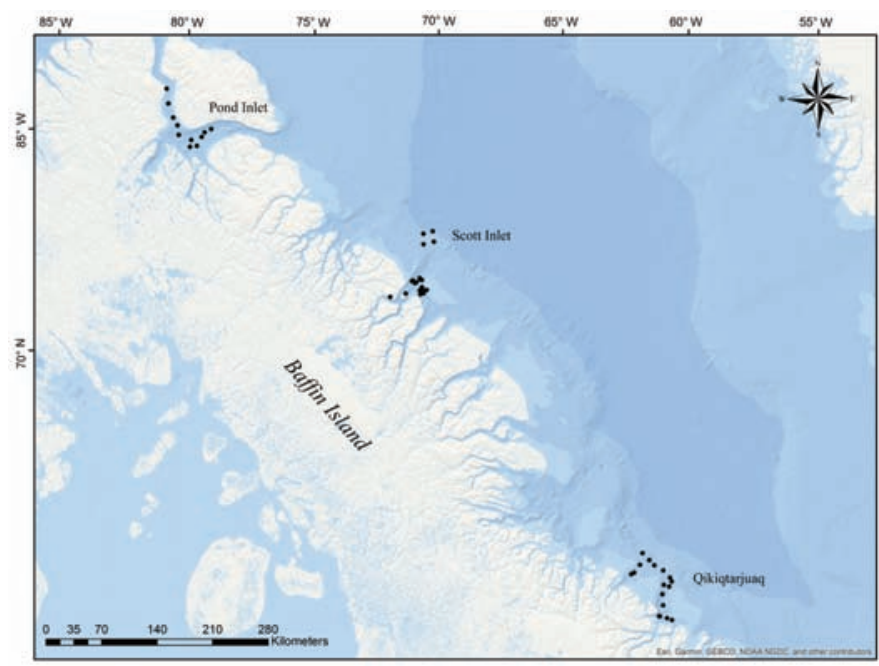

FIG. 1. Map of trawl locations from (north to south) Pond Inlet (2017), Scott Inlet (2013), and Qikiqtarjuaq (2017) on Baffin Island, Nunavut, Canada.

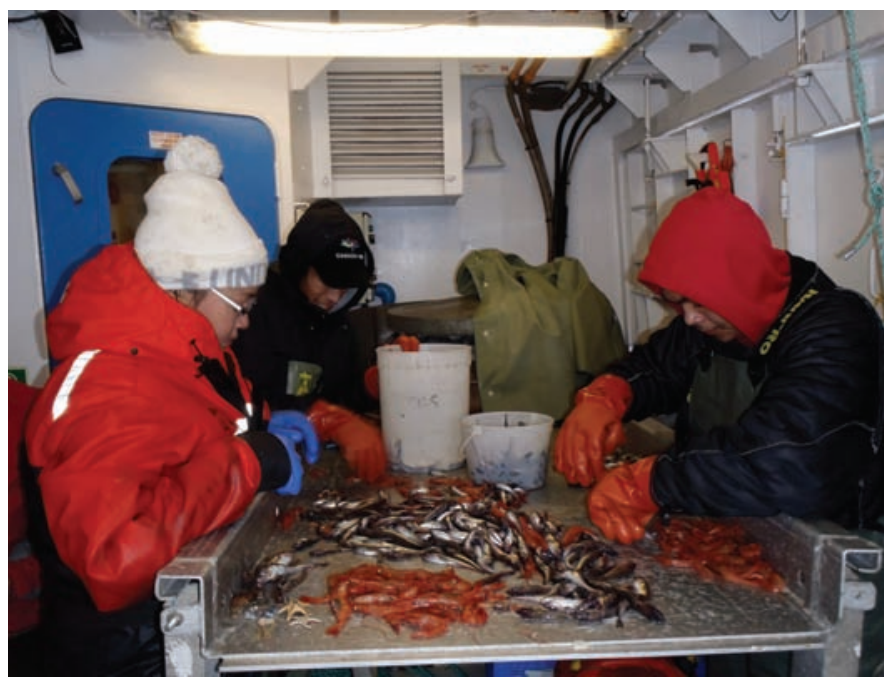

FIG. 2. Inuit science crew aboard the M.V. Nuliajuk sorting fishes and invertebrates caught in an otter trawl.

Benthic and pelagic primary productivity were quantified to determine the signatures of basal carbon sources by completing vertical zooplankton hauls (Fig. 4) and by grab sampling for benthic invertebrates.

\section{Chemical Tracer and Niche Analysis}

Tissue samples (muscle, liver, fin) will be analyzed for stable isotopes $\left(\delta^{13} \mathrm{C}\right.$ and $\left.\delta^{15} \mathrm{~N}\right)$. Samples were freeze dried (48 hours) at $-53^{\circ} \mathrm{C}$ using a Labconco freeze drier and then homogenized. Lipids will be removed using a 2:1 chloroform methanol solvent (performed once for muscle and twice for liver) and the remaining tissue will be weighed out in tin capsules using a Sartorius microgram balance. Stable isotope analysis will be completed at the Great Lakes Institute for Environmental Research 


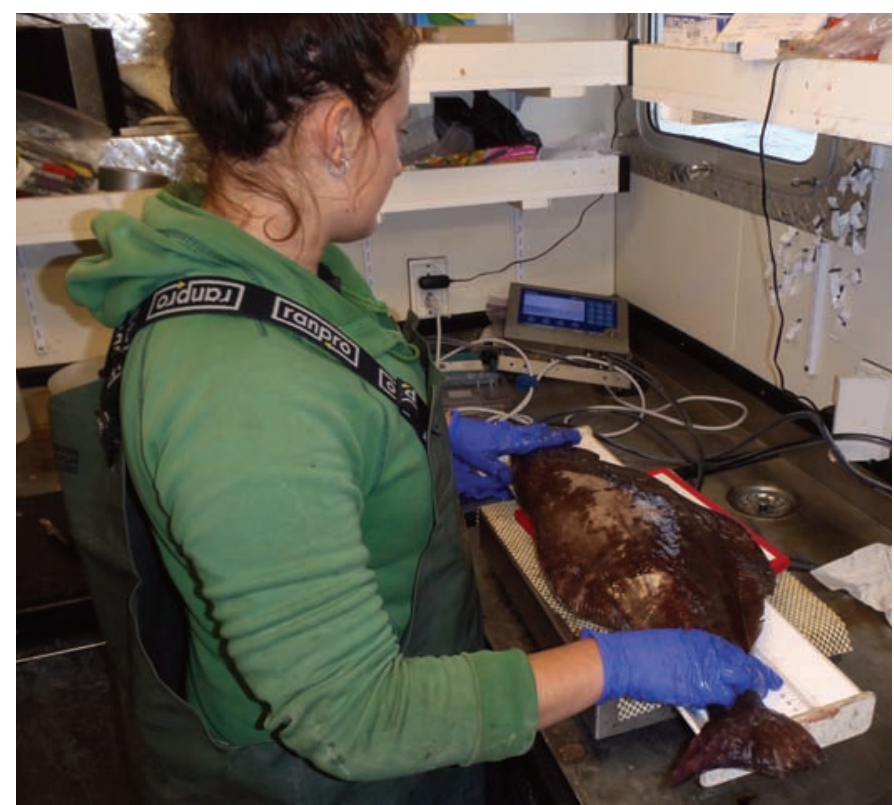

FIG. 3. Measuring morphometric characteristics of a Greenland halibut.

using a continuous flow Thermofinnigan Delta Plus mass spectrometer coupled with an elemental analyzer. Ratios of heavy to light nitrogen $\left({ }^{15} \mathrm{~N}:{ }^{14} \mathrm{~N}\right)$ and carbon $\left({ }^{13} \mathrm{C}:{ }^{12} \mathrm{C}\right)$ stable isotopes will be determined and compared to standard (Pee Dee Belemnite carbonate for $\delta^{13} \mathrm{C}$; atmospheric nitrogen for $\delta^{15} \mathrm{~N}$ ) and internal references.

Liver will be analyzed for H-Print, given that $\sim 70 \%$ of highly branched isoprenoid lipids are stored in this tissue (Brown et al., 2013). Liver tissue will be sent to the Scottish Association for Marine Science for extraction with analysis of HBI lipids and calculation of H-Print values using gas chromatography-mass spectrometry output. Mass spectral intensities of HBIs will be compared to authentic standards for identification and internal standards for quantification (Belt et al., 2012).

\section{Environmental Data}

Environmental factors such as water temperature, dissolved oxygen, salinity, and seasonal sea ice conditions were measured and will be compared to species niche and carbon contributions at the three sites (Fig. 1). Oceanographic data were collected from long-term fixed moorings with temperature loggers and shipborne conductivity-temperature-depth sensor casts, and sea-ice data was obtained from the Canadian Ice Service (which uses satellite data as well as ice observations from vessels, shores, and aircraft).

\section{Sampling Conducted to Date}

In fall 2013, longline and trawl surveys were completed in Scott Inlet using the M.V. Nuliajuk. In total, 21 trawls were completed spanning a depth range of 400 to $725 \mathrm{~m}$.

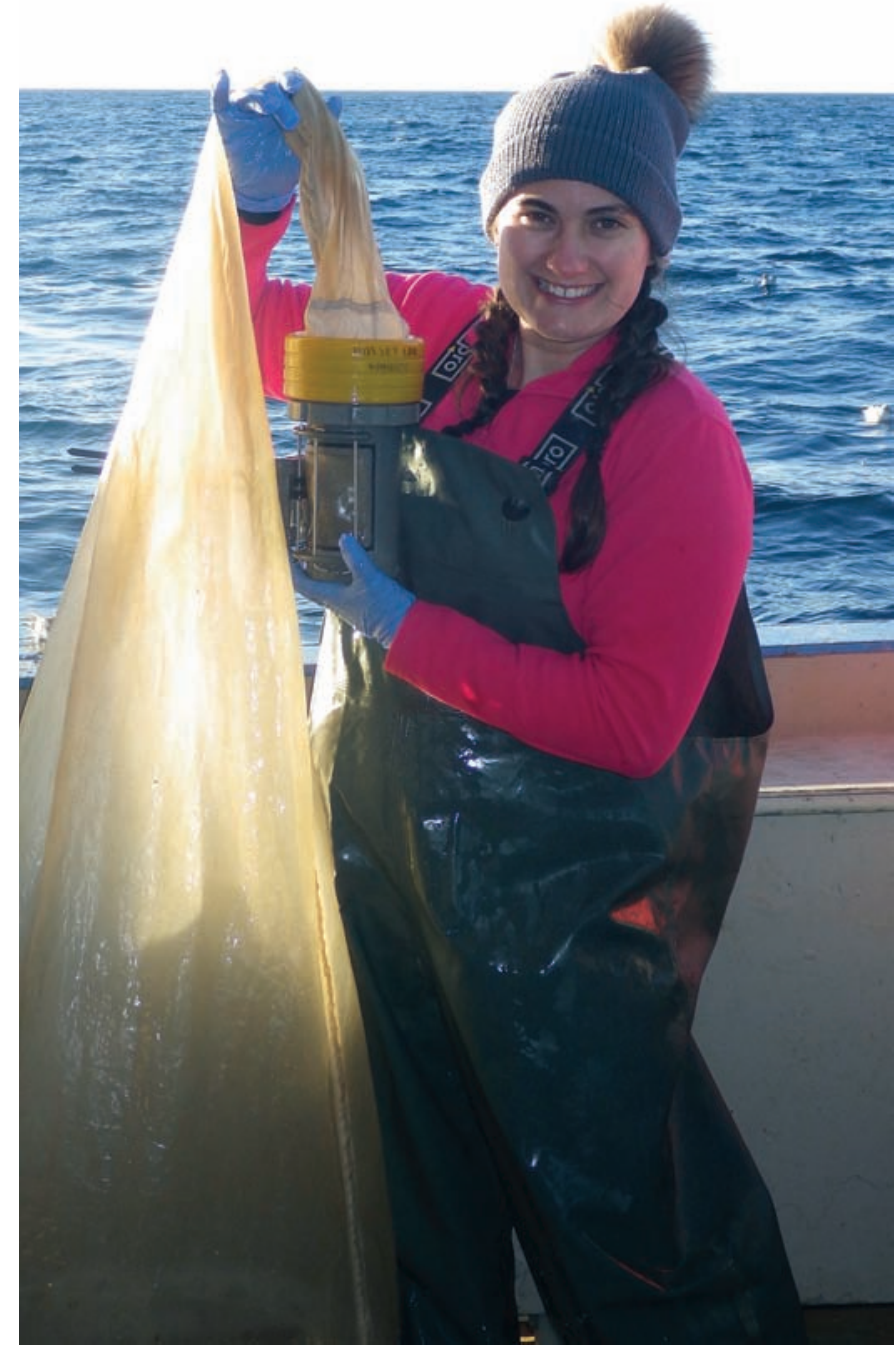

FIG. 4. Collecting zooplankton samples for baseline data to be analyzed for $\delta^{13} \mathrm{C}$ and $\delta^{15} \mathrm{~N}$.

During the late summer of 2017, trawls were completed in Eclipse Sound (Pond Inlet) (11 trawls, depth range 165 to $728 \mathrm{~m})$ and in the vicinity of Broughton Island (Qikiqtarjuaq) (17 trawls, depth range $185-653 \mathrm{~m}$ ). Sampling in 2018 included trawling at Pond Inlet and Qikiqtarjuaq in August and September. Catches included Greenland halibut (Reinhardtius hippoglossoides), Arctic cod (Boreogadus saida), Polar cod (Arctogadus glacialis), sculpins (i.e., Triglops pingelii, T. nybelini, Artediellus atlanticus), Arctic skate (Amblyraja hyperborea), eelpouts (Lycodes mcallisteri, L. rossi, L. eudipleurostictus), shrimp (Scleorcrangon sp., Eualus gaimardii, Pandalus borealis), sea tadpoles (Careproctus reinhardti), snail fish (Liparis fabricii, L. gibbus), American plaice (Hippoglossoides platessoides), Atlantic poachers (Leptagonus decagonus), echinoderm species, and other fishes and invertebrates. Tissue samples (muscle, liver, fin) from all captured species are currently being processed for chemical tracer analyses. 


\section{SIGNIFICANCE}

The Arctic marine environment is changing rapidly as a result of climate change and the ongoing and accelerating northward expansion of species from the south. It is critical that work be undertaken to help us understand how stressors are affecting the structure and stability of ecosystems, particularly deep-water food webs, to enable us to better predict how these communities will respond to changes, and to provide baseline data for future monitoring work on deep-water environments.

Deep-water food webs have received little attention from researchers. There are growing pressures to exploit and explore species in deep-waters (Hussey et al., 2017) with more than 300 exploitable deep-water species worldwide (Priede, 2017). These pressures are of concern because deepwater ecosystems are low-light (Drazon and Sutton, 2017; Priede, 2017), cold environments (approximately $4^{\circ} \mathrm{C}$; Priede, 2017), where most species are highly $k$-selected with slow growth rates, longevity, late maturity (Norse et al., 2012; Victorero et al., 2018), low metabolism (Victorero et al., 2018), and a narrow dietary niche (Drazon and Sutton, 2017). Arctic deep-water ecosystems are particularly susceptible to climate change and acidification because carbon dioxide dissolves more quickly in cold water, ventilation is reduced, and organic material has increased residence time (Chen et al., 2017). Ongoing climate effects have the potential to alter conditions for deep-water species, with unknown ecological consequences (Levin and Le Bris, 2015).

In Nunavut, there is currently only one communitybased commercial fishery for Greenland halibut (Hussey et al., 2017). The fishery started in 1986 (Coad and Reist, 2017) and is operated out of the community of Pangnirtung. Because of its success, other northern communities are interested in developing local fisheries (Barkley et al., 2018). An understanding of deep-water food webs and species interactions in the eastern Canadian Arctic will provide a baseline to assist the development of these communitybased test fisheries. In addition, exploration of deep-water food webs is identifying new opportunities for subsistence fishing (e.g., shrimp fisheries, clam digging during low tide) to address food security issues in Arctic communities.

Throughout this project, local communities have participated in all aspects of research through co-planning of projects with Hunters and Trappers Organizations (community organizations involved in subsistence harvesting, sharing, and management of local research) and the employment and training of Inuit science staff in the use of fishing gear and sampling procedures. In addition, the incorporation of traditional knowledge (Inuit Qaujimajatuqangit) through community meetings and discussions is central to the success of research and its impact on northern communities (Riedlinger and Berkes, 2001). Hearing northern perspectives on how changes are influencing communities is crucial to incorporating this knowledge (Pearce et al., 2015) and to understanding the impacts of climate change (Riedlinger and Berkes, 2001).
Deep-water species are not typically subjects of detailed traditional knowledge because historically these species were not commonly encountered (Idrobo and Berkes, 2012). For example, in the past Inuit Qaujimajatuqangit did not include deep-water species such as grenadiers (roughhead grenadier, Macrourus berglax and roundnose grenadier, Coryphaenoides rupestris; Devine et al., 2006), but the development of the Greenland halibut fishery in Pangnirtung has advanced knowledge of these species through direct experience. Grenadiers are a bycatch of the fishery, and community members have introduced them into their diet.

Overall, results from this study will be used to aid sustainable fishery development in the North, which will provide needed opportunities for economic growth, employment, and food security and will improve the well-being of Arctic communities. In addition, by completing an assessment at the ecosystem (multi-species) level rather than focusing on a single species, this research will foster an ecosystem-based approach to resource management and conservation.

\section{ACKNOWLEDGEMENTS}

I am honoured to be the recipient of the 2018 Jennifer Robinson Memorial Scholarship and would like to thank the Arctic Institute of North America and the selection committee for this opportunity. I would like to thank my supervisor, Dr. Nigel Hussey from the University of Windsor, Dr. Kevin Hedges from Fisheries and Oceans Canada, and Dr. Thomas Brown from the Scottish Association for Marine Science for their unconditional guidance. Without the support of the Hussey lab staff, graduate students, and volunteers, this work would not be possible. Thank you to the Hunters and Trappers Organizations as well as to all of the M.V. Nuliajuk crew and Inuit science crew for their assistance in collecting samples and for supporting our work.

Additional funding and support for this project came from the National Sciences and Engineering Research Council of Canada, Fisheries and Oceans Canada, the Garfield Weston Foundation, Northern Studies Training Program, Marine Stewardship Council, Canadian Northern Economic Development Agency, the Association of Canadian Universities for Northern Studies and the Government of Nunavut.

\section{REFERENCES}

Barkley, A.N., Fisk, A.T., Hedges, K.J., Treble, M.A., and Hussey, N.E. 2018. Transient movements of a deep-water flatfish in coastal waters: Implications of inshore-offshore connectivity for fisheries management. Journal of Applied Ecology 55(3): $1071-1081$.

https://doi.org/10.1111/1365-2664.13079

Belt, S.T., Massé, G., Rowland, S.J., Poulin, M., Michel, C., and LeBlanc, B. 2007. A novel chemical fossil of palaeo sea ice: $\mathrm{IP}_{25}$. Organic Geochemistry 38(1):16-27.

https://doi.org/10.1016/j.orggeochem.2006.09.013 
Belt, S.T., Brown, T.A., Rodriguez, A.N., Sanz, P.C., Tonkin, A., and Ingle, R. 2012. A reproducible method for the extraction, identification and quantification of the Arctic sea ice proxy $\mathrm{IP}_{25}$ from marine sediments. Analytical Methods 4(3):705-713.

Belt, S.T., Brown, T.A., Smik, L., Tatarek, A., Wiktor, J., Stowasser, G., Assmy, P., Allen, C.S. and Husum, K. 2017. Identification of $\mathrm{C}_{25}$ highly branched isoprenoid (HBI) alkenes in diatoms of the genus Rhizosolenia in polar and sub-polar marine phytoplankton. Organic Geochemistry 110:65-72. https://doi.org/10.1016/j.orggeochem.2017.05.007

Bergmann, M., Dannheim, J., Bauerfeind, E., and Klages, M. 2009. Trophic relationships along a bathymetric gradient at the deep-sea observatory HAUSGARTEN. Deep Sea Research Part I: Oceanographic Research Papers 56(3):408-424.

https://doi.org/10.1016/j.dsr.2008.10.004

Bison, M., Ibanez, S., Redjadj, C., Boyer, F., Coissac, E., Miquel, C., Rioux, D., et al. 2015. Upscaling the niche variation hypothesis from the intra- to the inter-specific level. Oecologia 179(3):835-842.

https://doi.org/10.1007/s00442-015-3390-7

Brown, T.A. 2018. Stability of the lipid biomarker H-Print within preserved animals. Polar Biology 41(9):1901-1905.

https://doi.org/10.1007/s00300-018-2317-2

Brown, T.A., and Belt, S.T. 2012. Closely linked sea ice-pelagic coupling in the Amundsen Gulf revealed by the sea ice diatom biomarker IP ${ }_{25}$. Journal of Plankton Research 34(8):647-654. https://doi.org/10.1093/plankt/fbs045

-2017. Biomarker-based H-Print quantifies the composition of mixed sympagic and pelagic algae consumed by Artemia sp. Journal of Experimental Marine Biology and Ecology 488:32-37.

https://doi.org/10.1016/j.jembe.2016.12.007

Brown, T.A., Belt, S.T., Ferguson, S.H., Yurkowski, D.J., Davison, N.J., Barnett, J.E.F., and Jepson, P.D. 2013. Identification of the sea ice diatom biomarker $\mathrm{IP}_{25}$ and related lipids in marine mammals: A potential method for investigating regional variations in dietary sources within higher trophic level marine systems. Journal of Experimental Marine Biology and Ecology 441:99-104.

https://doi.org/10.1016/j.jembe.2013.01.020

Brown, T.A., Yurkowski, D.J., Ferguson, S.H., Alexander, C., and Belt, S.T. 2014a. H-Print: A new chemical fingerprinting approach for distinguishing primary production sources in Arctic ecosystems. Environmental Chemistry letters 12(3):387-392. https://doi.org/10.1007/s10311-014-0459-1

Brown, T.A., Alexander, C., Yurkowski, D.J., Ferguson, S.H., and Belt, S.T. 2014b. Identifying variable sea ice carbon contributions to the Arctic ecosystem: A case study using highly branched isoprenoid lipid biomarkers in Cumberland Sound ringed seals. Limnology and Oceanography 59(5):1581 - 1589. https://doi.org/10.4319/1o.2014.59.5.1581

Brown, T.A., Hegseth, E.N., and Belt, S.T. 2015. A biomarkerbased investigation of the mid-winter ecosystem in Rijpfjorden, Svalbard. Polar Biology 38(1):37-50.

https://doi.org/10.1007/s00300-013-1352-2
Brown, T.A., Belt, S.T., Gosselin, M., Levasseur, M., Poulin, M., and Mundy, C.J. 2016. Quantitative estimates of sinking sea ice particulate organic carbon based on the biomarker $\mathrm{IP}_{25}$. Marine Ecology Progress Series 546:17-29.

https://doi.org/10.3354/meps11668

Brown, T.A., Assmy, P., Hop, H., Wold, A., and Belt, S.T. 2017a. Transfer of ice algae carbon to ice-associated amphipods in the high-Arctic pack ice environment. Journal of Plankton Research 39(4):664-674. https://doi.org/10.1093/plankt/fbx030

Brown, T.A., Chrystal, E., Ferguson, S.H., Yurkowski, D.J., Watt, C., Hussey, N.E., and Belt, S.T. 2017b. Coupled changes between the H-Print biomarker and $\delta^{15} \mathrm{~N}$ indicates a variable sea ice carbon contribution to the diet of Cumberland Sound beluga whales. Limnology and Oceanography 62(4):1606-1619. https://doi.org/10.1002/1no.10520

Brown, T.A., Galicia, M.P., Thiemann, G.W., Belt, S.T., Yurkowski, D.J., and Dyck, M.G. 2018. High contributions of sea ice derived carbon in polar bear (Ursus maritimus) tissue. PloS ONE 13(1): e0191631. https://doi.org/10.1371/journal.pone.0191631

Carton, J.A., Ding, Y., and Arrigo, K.R. 2015. The seasonal cycle of the Arctic Ocean under climate change. Geophysical Research Letters 42(18):7681-7686. https://doi.org/10.1002/2015GL064514

Chen, C.-T.A., Lui, H.-K., Hsieh, C.-H., Yanagi, T., Kosugi, N., Ishii, M., and Gong, G.-C. 2017. Deep oceans may acidify faster than anticipated due to global warming. Nature Climate Change 7(12):890-894.

Coad, B.W., and Reist, J.D. 2017. Marine fishes of Arctic Canada. Toronto, Ontario: University of Toronto Press.

Colwell, R.K., and Rangel, T.F. 2009. Hutchinson's duality: The once and future niche. Proceedings of the National Academy of Sciences 106(Suppl. 2):19651-19658.

https://doi.org/10.1073/pnas.0901650106

Demopoulos, A.W.J., McClain-Counts, J., Ross, S.W., Brooke, S., and Mienis, F. 2017. Food-web dynamics and isotopic niches in deep-sea communities residing in a submarine canyon and on the adjacent open slopes. Marine Ecology Progress Series 578:19-33. https://doi.org/10.3354/meps12231

Devine, J.A., Baker, K.D., and Haedrich, R.L. 2006. Fisheries: Deep-sea fishes qualify as endangered. Nature 439(7072):29.

Drazen, J.C., and Sutton, T.T. 2017. Dining in the deep: The feeding ecology of deep-sea fishes. Annual Review of Marine Science 9:337-366. https://doi.org/10.1146/annurev-marine-010816-060543

Harada, N. 2016. Review: Potential catastrophic reduction of sea ice in the western Arctic Ocean: It's impact on biogeochemical cycles and marine ecosystems. Global and Planetary Change 136:1-17. https://doi.org/10.1016/j.gloplacha.2015.11.005

Heady, W.N., and Moore, J.W. 2013. Tissue turnover and stable isotope clocks to quantify resource shifts in anadromous rainbow trout. Oecologia 172(1):21-34.

https://doi.org/10.1007/s00442-012-2483-9 
Hussey, N.E., Hedges, K.J., Barkley, A.N., Treble, M.A., Perklova, I., Webber, D.M., Ferguson, S.H., et al. 2017. Movements of a deep-water fish: Establishing marine fisheries management boundaries in coastal Arctic waters. Ecological Applications 27(3): $687-704$.

https://doi.org/10.1002/eap.1485

Idrobo, C.J., and Berkes, F. 2012. Pangnirtung Inuit and the Greenland shark: Co-producing knowledge of a little discussed species. Human Ecology 40(3):405-414.

https://doi.org/10.1007/s10745-012-9490-7

Iken, K., Bluhm, B.A., and Gradinger, R. 2005. Food web structure in the high Arctic Canada Basin: Evidence from $\delta^{13} \mathrm{C}$ and $\delta^{15} \mathrm{~N}$ analysis. Polar Biology 28(3):238-249.

https://doi.org/10.1007/s00300-004-0669-2

Inger, R., and Bearhop, S. 2008. Applications of stable isotope analyses to avian ecology. Ibis 150(3):447-461. https://doi.org/10.1111/j.1474-919X.2008.00839.x

Jackson, A.L., Inger, R., Parnell, A.C., and Bearhop, S. 2011. Comparing isotopic niche widths among and within communities: SIBER - Stable Isotope Bayesian Ellipses in R. Journal of Animal Ecology 80(3):595-602.

https://doi.org/10.1111/j.1365-2656.2011.01806.x

Kortsch, S., Primicerio, R., Fossheim, M., Dolgov, A.V., and Aschan, M. 2015. Climate change alters the structure of Arctic marine food webs due to poleward shifts of boreal generalists. Proceedings of the Royal Society B: Biological Sciences 282(1814). 9 p.

https://doi.org/10.1098/rspb.2015.1546

Levin, L.A., and Le Bris, N. 2015. The deep ocean under climate change. Science 350(6262):766-768.

https://doi.org/10.1126/science.aad0126

McMeans, B.C., McCann, K.S., Humphries, M., Rooney, N., and Fisk, A.T. 2015. Food web structure in temporally-forced ecosystems. Trends in Ecology \& Evolution 30(11):662 - 672.

https://doi.org/10.1016/j.tree.2015.09.001

Newsome, S.D., del Rio, C.M., Bearhop, S., and Phillips, D.L. 2007. A niche for isotopic ecology. Frontiers in Ecology and the Environment 5(8):429-436.

https://doi.org/10.1890/060150.1

Norse, E.A., Brooke, S., Cheung, W.W.L., Clark, M.R., Ekeland, I., Froese, R., Gjerde, K.M., et al. 2012. Sustainability of deepsea fisheries. Marine Policy 36(2):307-320.

https://doi.org/10.1016/j.marpol.2011.06.008

Pearce, T., Ford, J., Cunsolo Willox, A., and Smit, B. 2015. Inuit traditional ecological knowledge (TEK) subsistence hunting and adaption to climate change in the Canadian Arctic. Arctic 68(2):233-245.

https://doi.org/10.14430/arctic4475

Phillips, D.L., Inger, R., Bearhop, S., Jackson, A.L., Moore, J.W., Parnell, A.C., Semmens, B.X., and Ward, E.J. 2014. Best practices for use of stable isotope mixing models in food-web studies. Canadian Journal of Zoology 92(10):823 - 835.

https://doi.org/10.1139/cjz-2014-0127
Post, D.M. 2002. Using stable isotopes to estimate trophic position: Models, methods, and assumptions. Ecology 83(3):703-718. https://doi.org/10.1890/0012-9658(2002)083[0703:USITET]2.0 $\mathrm{CO} ; 2$

Preciado, I., Cartes, J.E., Punzón, A., Frutos, I., López-López, L., and Serrano, A. 2017. Food web functioning of the benthopelagic community in a deep-sea seamount based on diet and stable isotope analyses. Deep Sea Research Part II: Topical Studies in Oceanography 137:56-68.

https://doi.org/10.1016/j.dsr2.2016.07.013

Priede, I.G. 2017. Deep-sea fishes: Biology, diversity, ecology and fisheries. Cambridge: Cambridge University Press.

Riedlinger, D., and Berkes, F. 2001. Contributions of traditional knowledge to understanding climate change in the Canadian Arctic. Polar Record 37(203):315-328.

https://doi.org/10.1017/S0032247400017058

Rogers, A.D. 2015. Environmental change in the deep ocean. Annual Review of Environment and Resources 40:1-38.

https://doi.org/10.1146/annurev-environ-102014-021415

Turner, T.F., Collyer, M.L., and Krabbenhoft, T.J. 2010. A general hypothesis-testing framework for stable isotope ratios in ecological studies. Ecology 91(8):2227-2233.

https://doi.org/10.1890/09-1454.1

Valls, M., Sweeting, C.J., Olivar, M.P., Fernández de Puelles, M.L., Pasqual, C., Polunin, N.V.C., and Quetglas, A. 2014. Structure and dynamics of food webs in the water column on shelf and slope grounds of the western Mediterranean. Journal of Marine Systems 138:171 - 181 .

https://doi.org/10.1016/j.jmarsys.2014.04.002

Vander Zanden, M.J., Clayton, M.K., Moody, E.K., Solomon, C.T., and Weidel, B.C. 2015. Stable isotope turnover and halflife in animal tissues: A literature synthesis. PLoS ONE 10(1): e0116182.

https://doi.org/10.1371/journal.pone.0116182

Victorero, L., Watling, L., Deng Palomares, M.L., and Nouvian, C. 2018. Out of sight, but within reach: A global history of bottom-trawled deep-sea fisheries from $>400 \mathrm{~m}$ depth. Frontiers in Marine Science 5: Article 98. https://doi.org/10.3389/fmars.2018.00098

Xia, B., Gao, Q.-F., Li, H., Dong, S.-L., and Wang, F. 2013. Turnover and fractionation of nitrogen stable isotope in tissues of grass carp Ctenopharyngodon idellus. Aquaculture Environment Interactions 3(2):177-186.

https://doi.org/10.3354/aei00061

Zimmo, S., Blanco, J., and Nebel, S. 2012. The use of stable isotopes in the study of animal migration. Nature Education Knowledge 3(12):3.

Laurissa Christie is currently a Master of Science student in Biological Sciences at the University of Windsor. She is the 2018 recipient of the Jennifer Robinson Memorial Scholarship. laurissa.christie@gmail.com 